\title{
Peningkatan Motivasi dan Hasil Belajar Fisika Melalui Pembelajaran Berorientasi Pendekatan Inkuiri di Kelas XI IPA-1 SMAN 1 Batang Gasan
}

\author{
$\operatorname{Aspar}^{1 *}$ \\ ${ }^{1}$ Guru SMA Negeri 1 Batang Gasan \\ Jalan Sungai Sarik - Tiku, Km 28 Kabupaten Padang Pariaman \\ *Email: asparkoto@yahoo.co.id
}

\section{Article History}

Received: 9 Juni 2020

Reviewed: 19 Juni 2020

Published: 30 Juni 2020

Key Words

Physics learning; Inquiry approach; Motivation; Learning outcomes.

\begin{abstract}
Teacher-centered learning in Physics subject produces passive students because teachers dominate learning while students tend to listen, take notes, and do assignments. This condition does not provide space for students to be actively and creatively involved during learning which in turn decreases students' motivation and learning outcomes This condition can be improved through inquiry approach. The research aimed to increase motivation and learning outcomes in Physics through inquiry-based learning. The study employed Classroom Action Research (CAR) method in class XI IPA-1 SMAN 1 Batang Gasan in 2018/2019 Academic Year. This study consisted of 2 cycles in which each cycle consisted of planning, action, observation and reflection. Students' learning motivation data were collected using questionnaire sheets and their learning outcomes were collected through test. The results showed that inquiry-based learning increased student motivation from $68 \%$ in the first cycle to $100 \%$ in the second cycle and classical mastery of learning from $50 \%$ in cycle I to $96.4 \%$ in cycle II. It was concluded that inquiry-based learning approaches improve student motivation and learning outcomes in physics.
\end{abstract}

\section{PENDAHULUAN}

\section{A. Latar Belakang}

Fisika merupakan cabang sains yang dalam kehidupan sehari-hari sangat banyak digunakan. Kenapa sebagian benda-benda dapat menghantarkan panas dengan baik namun sebagian lagi bahkan tidak dapat menghantarkan panas? Ini dapat dijelaskan dengan mempelajari fisika. Kemajuan teknologi informasi seperti televisi, radio, bahkan internet juga tidak lepas dari fisika.
Mengingat begitu besarnya kontribusi fisika dalam kehidupan maka mempelajari fisika seharusnya adalah sesuatu yang menarik. Selama belajar fisika seharusnya siswa aktif, antusias, dan termotivasi mengikuti pembelajaran. Siswa yang termotivasi dalam belajar memiliki kreatifitas dan suka berinovasi. Untuk itu, menghadirkan pembelajaran fisika yang menarik, menantang dan menyenangkan bagi siswa adalah suatu kewajiban bagi guru di sekolah. 
Kenyataan pembelajaran fisika di lapangan masih jauh dari tujuan di atas. Pembelajaran yang dilaksanakan di kelas masih belum mampu memupuk sikap ilmiah dan kemampuan berfikir ilmiah siswa. Hasil observasi di SMAN 1 Batang Gasan menunjukkan siswa cenderung pasif menerima materi fisika, siswa tidak termotivasi belajar secara aktif. Pembelajaran cenderung belajar satu arah seperti dapat dilihat dari angket yang sudah disebarkan pada siswa tentang metode mengajar guru. Oleh sebab itu, agar motivasi dan kompetensi siswa dapat ditingkatkan sehingga hasil belajarnya meningkat diperlukan model pembelajaran yang tepat. Salah satunya, penggunaan model pembelajaran berorientasi pendekatan inkuiri oleh guru di kelas. Model pembelajaran ini memberi penekanan pada keterlibatan siswa secara aktif selama proses pembelajaran.

Menurut (Silberman, 2006) "Pada saat kegiatan belajar aktif peserta didik melakukan sebagian besar pekerjaan yang harus dilakukan. Mereka menggunakan otak-otak mereka untuk mempelajari gagasan-gagasan, memecahkan berbagai masalah, dan menerapkan apa yang mereka pelajari." Jadi siswa yang aktif selama pembelajaran akan menggunakan kemampuan otaknya secara maksimal. Pembelajaran akan menjadi menyenangkan karena siswa akan tertantang untuk berpikir kreatif dan inovatif.

Model pembelajaran berorientasi pendekatan inkuiri menuntut siswa untuk berpikir kritis dan analitis. Pada pembelajaran berorientasi pendekatan inkuiri siswa mencari sendiri masalah-masalah dalam pembelajaran. Jawaban masalah tersebut ditemukan sendiri oleh siswa (Sanjaya, 2008). Untuk itu dalam pelaksanaannya di kelas, pembelajaran berorientasi pendekatan inkuiri dapat dilakukan dengan menggunakan percobaan atau eksperimen

Pembelajaran berorientasi pendekatan inkuiri dilaksanakan dalam bentuk kegiatan ilmiah. Kegiatan ilmiah dalam bentuk percobaan sederhana ini bertujuan menuntun siswa menemukan sendiri konsep-konsep fisika. Lebih lanjut Jerome Bruner (Dahar, 2012) menyatakan:

"Belajar bermakna hanya dapat terjadi melalui belajar penemuan. Pengetahuan yang diperoleh melalui belajar penemuan bertahan lama dan mempunyai efek transfer yang lebih baik. Belajar penemuan meningkatkan penalaran dan kemampuan berpikir secara bebas dan melatih keterampilan kognitif untuk menemukan dan memecahkan masalah".

Melalui pembelajaran berorientasi pendekatan inkuiri diharapkan siswa mendapatkan pengalaman nyata menemukan sendiri pengetahuannya. Pengalaman ini menjadikan siswa makin tertantang menemukan konsep-konsep baru dalam fisika. Akhirnya pembelajaran fisika aktif, kreatif, menyenangkan dan berkualitas mudah terwujud. Pembelajaran fisika berkualitas adalah kunci untuk mendapatkan lulusan berkualitas, khususnya dalam mata pelajaran fisika. Hasil penelitian (Kusdiastuti, Harjono, Sahidu, \& Gunawan, 2016) menunjukkan model pembelajaran inkuiri berbantuan laboratorium virtual berpengaruh terhadap penguasaan konsep fisika.

Mengingat besarnya peran pembelajaran fisika berorientasi pendekatan inkuiri dalam meningkatkan aktivitas, kreativitas, dan motivasi siswa, penulis melakukan penelitian tindakan kelas dengan judul "Peningkatan Motivasi dan Hasil Belajar Fisika Siswa menggunakan Pembelajaran berorientasi Pendekatan Inkuiri di Kelas XI IPA-1 SMAN 1 Batang Gasan Tahun Pembelajaran 2018/2019”

\section{B. Rumusan Masalah}

Masalah penelitian dirumuskan:

1. Apakah pembelajaran fisika berorientasi pendekatan inkuiri meningkatkan dapat meningkatkan motivasi belajar siswa?

2. Apakah pembelajaran fisika berorientasi pendekatan inkuiri dapat meningkatkan hasil belajar fisika siswa?

\section{Tujuan Penelitian} bahwa:

Tujuan penelitian adalah mengetahui

1. Pembelajaran fisika berorientasi pendekatan inkuiri dapat meningkatkan motivasi belajar siswa;

2. Pembelajaran fisika berorientasi pendekatan inkuiri dapat meningkatkan hasil belajar fisika siswa?

\section{Manfaat Penelitian}

Manfaat penelitian yaitu:

1. Variasi model pembelajaran di kelas lebih banyak sehingga guru punya keleluasaan memilih model yang tepat dan hasil belajar siswa meningkat; 
2. Menjadi referensi bagi guru dan peneliti lain dalam melaksanakan pembelajaran berorientasi pendekatan inkuiri di kelas, baik untuk mata pelajaran fisika ataupun mata pelajaran lainnya.

\section{E. Hipotesis Tindakan} melalui:

Hipotesis tindakan yang digunakan yaitu

1. Pembelajaran fisika berorientasi pendekatan inkuiri motivasi belajar siswa dapat ditingkatkan;

2. Pembelajaran fisika berorientasi pendekatan inkuiri hasil belajar siswa dapat ditingkatkan.

\section{METODE PENELITIAN}

\section{A. Jenis Penelitian}

Penelitian yang dilakukan merupakan penelitian tindakan kelas (PTK). Peneliti terlibat langsung selama proses penelitian, mulai merencanakan hingga penyusunan laporan penelitian.

\section{B. Setting Penelitian}

1. Lokasi Penelitian

Penelitian dilakukan di kelas XI IPA-1 SMAN 1 Batang Gasan Tahun Pembelajaran 2018/2019 semester 1.

2. Subjek Penelitian

Siswa kelas XI IPA-1 SMAN 1 Batang Gasan Tahun Pembelajaran 2018/2019 semester 1 menjadi subjek pada penelitian ini. Jumlah siswa adalah 28 orang, yaitu 12 orang laki-laki dan 16 orang perempuan.
3. Waktu Penelitian

Penelitian dilaksanakan pada semester I Tahun Pembelajaran 2018/2019 yang dimulai pada bulan Oktober hingga Desember 2018.

\section{Prosedur Penelitian}

Prosedur PTK dilaksanakan dengan 4 komponen kegiatan yang dinamakan siklus. Komponen-komponen tersebut meliputi perencanaan, tindakan, pengamatan, dan refleksi tiap siklusnya.

\section{Teknik dan Instrumen Pengumpul Data}

Data penelitian diperoleh menggunakan lembar pengamatan, angket respon siswa dan catatan lapangan untuk motivasi belajar siswa. Tes hasil belajar digunakan untuk mendapatkan data hasil belajar siswa. Angket respon siswa menggunakan skala Likert. Adapun kategorinya dapat dilihat pada Tabel 1 .

\section{E. Teknik Analisa Data}

1. Data angket respon siswa

Untuk mengkonversi data angket respon siswa dari skala 1-4 menjadi skala (0-100) digunakan persamaan:

$$
N M=\frac{S}{N T} \times 100
$$

Keterangan;

NM : nilai motivasi

S : skor yang diperoleh siswa

NT : nilai total

Dimodifikasi dari (Riduan, 2009)

Hasil yang diperoleh dikategorikan berdasarkan kategori pada Tabel 2

Tabel 1. Kategori Skala Likert untuk Angket Respon Siswa

\begin{tabular}{ccll}
\hline No & Skor & Kategori & Ket \\
\hline 1 & 4 & sangat setuju & \\
2 & 3 & Setuju & \\
3 & 2 & tidak setuju \\
4 & 1 & sangat tidak setuju & \\
\hline
\end{tabular}

Tabel 2: Kategori Motivasi Siswa

\begin{tabular}{cl}
\hline Nilai Motivasi $(\mathrm{NM})$ & Kategori \\
\hline $0-20$ & Sangat tidak termotivasi \\
$21-40$ & Tidak termotivasi \\
$41-60$ & Kurang termotivasi \\
$61-80$ & Termotivasi \\
$81-100$ & Sangat termotivasi \\
\hline
\end{tabular}

Dimodifikasi dari (Riduan, 2009) 
2. Data tes hasil belajar

Data hasil belajar siswa didapat dari tes hasil belajar yang dilakukan di akhir siklus. Data ini mengidentifikan ketuntasan belajar individual siswa. Ketuntasan belajar individual didasarkan Kriteria Ketuntasan Belajar Minimal (KKM). Penetapan KKM dilakukan di awal pembelajaran. Sedangkan ketuntasan belajar klasikal ditentukan dengan persamaan:

$$
K K=\frac{J T}{N} X 100 \%
$$

Keterangan:

KK : ketuntasan klasikal

JT : jumlah ketuntasan individual

$\mathrm{N}$ : jumlah seluruh siswa

Adapun persentase ketuntasan belajar individual dihitung setiap siswa pada tiap siklus dengan persamaan berikut ini.

$$
K I=\frac{S S}{S M} X 100 \%
$$

Keterangan:

KI : ketuntasan individual

SS : Skor diperoleh siswa

SM : Skor maksimum tes

\section{HASIL DAN PEMBAHASAN}

Penelitian dilaksanakan selama 2,5 bulan dengan dua siklus. Tiap siklus dilaksanakan masing-masing sebanyak 4 pertemuan tatap muka.

\section{A. Deskripsi Data Motivasi Belajar Siklus I}

Angket respon siswa memberikan data motivasi belajar pada tiap siklus. Tabel 3 merangkum motivasi belajar siswa siklus I.

Tabel 3 menggambarkan bahwa motivasi siswa yang dikenakan tindakan (action) pembelajaran menggunakan pendekatan inkuiri kurang maksimal. Terlihat masih terdapat 9 siswa atau 32\% masih kurang termotivasi.

\section{B. Deskripsi Data Hasil Belajar Siklus I}

Setelah tindakan pada siklus I dilaksanakan tes hasil belajar. Rangkuman hasil tes hasil belajar. Tabel 4 memperlihatkan bahwa berdasarkan nilai KKM terdapat 14 orang siswa dinyatakan tuntas sedangkan 14 orang siswa belum tuntas. Artinya baru 50\% ketuntasan klasikal yang tercapai.

\section{Refleksi Siklus I}

Data siklus I dianalisis bersamaan dengan data hasil observasi dan catatan lapangan. Hasilnya menunjukkan motivasi dan hasil belajar siswa belum maksimal ditingkatkan.

Masih terdapat 32\% siswa yang kurang termotivasi belajar fisika. Pengamatan lapangan memperlihatkan masih terdapat siswa yang belum terlibat aktif selama pembelajaran berlangsung. Hanya sebagian siswa yang aktif bekerja dalam kegiatan percobaan dan diskusi.

$$
\text { Pengamatan selama kegiatan }
$$
pembelajaran dan catatan lapangan selama siklus I menunjukkan bahwa:

a. Media pembelajaran perlu dibuat lebih variatif dan menarik;

b. Percobaan perlu dibuat lebih sederhana dan alat dan bahan lebih mudah diperoleh siswa;

c. Motivasi belajar masih rendah dan perlu ditingkatkan pada siklus berikutnya;

d. ketuntasan hasil belajar secara klasikal masih rendah;

e. Miskonsepsi terhadap suatu konsep sehingga perlu penekanan di akhir diskusi kelas terhadap konsep-konsep fisika yang telah dirumuskan dan disimpulkan;

f. Rumusan kalimat tes hasil belajar yang lebih operasional sehingga lebih mudah dipahami oleh siswa.

Tabel 3. Data Motivasi Belajar Siklus I

\begin{tabular}{cccc}
\hline & \multicolumn{3}{c}{ Kategori Motivasi } \\
\cline { 2 - 4 } Jumlah Siswa & Kurang Termotivasi & Termotivasi & Sangat Termotivasi \\
\hline
\end{tabular}

Tabel 4. Deskripsi Data Hasil Belajar Siklus I

\begin{tabular}{ccc}
\hline & \multicolumn{2}{c}{ Kategori } \\
\cline { 2 - 3 } Jumlah Siswa & Tidak Tuntas & Tuntas \\
\hline
\end{tabular}


Hasil refleksi di atas memberikan gambaran bagi peneliti diperbaiki pada tindakan siklus berikutnya. Adapun perbaikan tersebut adalah sebagai berikut:

a. Mempertahankan sikap dan hal positif yang ada dalam siklus I;

b. Guru memotivasi siswa untuk bertanya, mencari sumber yang relevan, dan mempresentasikan hasil ke depan;

c. Menyiapkan media pembelajaran yang inovatif dan menarik;

d. Merancang percobaan sederhana dan siswa familiar serta mudah menemukan alat dan bahan percobaan tersebut di lingkungannya.

\section{Deskripsi Data Motivasi Belajar Siklus II}

Data motivasi belajar yang diperoleh melalui angket respon siswa terhadap pembelajaran pada siklus II dirangkum sebagai berikut (lihat Tabel 5).

Tabel 5 memperlihatkan bahwa motivasi siswa selama proses pembelajaran berorientasi pendekatan inkuiri meningkat dibandingkan siklus sebelumnya. Siswa yang sangat termotivasi adalah 21 orang atau $75 \%$. Sebaliknya tidak terdapat siswa yang kurang termotivasi.

\section{E. Deskripsi Data Hasil Belajar Siklus II}

Setelah tindakan pada siklus II dilaksanakan tes hasil belajar. Rangkuman hasil tes hasil belajar adalah (lihat Tabel 6). Tabel 6 memperlihatkan bahwa 27 orang atau $93 \%$ siswa yang mengikuti pembelajaran fisika berorientasi pendekatan inkuiri telah mencapai ketuntasan belajar.

\section{F. Refleksi Siklus II}

Setelah tindakan dilaksanakan refleksi pada akhir siklus II. Refleksi didasarkan analisis hasil pengamatan, catatan lapangan, dan tes hasil belajar.

Refleksi terhadap pelaksanaan siklus II terutama aspek motivasi dan hasil belajar siswa. Analisis catatan lapangan, data angket respon belajar siswa, dan data tes hasil belajar siswa menggambarkan bahwa selama tindakan pada siklus II:

a. Motivasi belajar meningkat signifikan sehingga masalah pada siklus I terselesaikan;

b. Data menunjukkan persentase siswa yang termotivasi sudah mencapai hasil yang diharapkan, yakni $28 \%$ termotivasi dan $72 \%$ sangat termotivasi;

c. Ketuntasan belajar klasikal mencapai $93 \%$. Ini berarti perbaikan pada siklus II memberikan peningkatan yang signifikan pada hasil belajar.

\section{G. Peningkatan Siklus I ke Siklus II 1. Motivasi Belajar Siswa}

Data angket respon siswa dianalisis untuk melihat peningkatan motivasi belajar siswa. Hasilnya menunjukkan peningkatan yang signifikan rata-rata motivasi belajar fisika tiap siklus. Tabel 7 menggambarkan peningkatan tersebut.

Tabel 5. Data Motivasi Belajar Siklus II

\begin{tabular}{cccc}
\hline & \multicolumn{3}{c}{ Kategori Motivasi } \\
\cline { 2 - 4 } Jumlah Siswa & Kurang Termotivasi & Termotivasi & Sangat Termotivasi \\
\hline
\end{tabular}

Tabel 6. Data Hasil Belajar pada Siklus II

\begin{tabular}{ccc}
\hline & \multicolumn{2}{c}{ Kategori } \\
\cline { 2 - 3 } Jumlah Siswa & Tidak Tuntas & Tuntas \\
& 1 orang & 27 orang \\
\hline
\end{tabular}


Tabel 7 memperlihatkan peningkatan motivasi belajar siswa pada setiap siklus. Siswa yang kurang termotivasi pada siklus I masih terdapat $32 \%$ sedangkan siswa sangat termotivasi hanya $14 \%$. Namun tidak terdapat siswa yang kurang termotivasi pada siklus II. Sebaliknya siswa terdapat $72 \%$ siswa yang sangat termotivasi. Data tersebut menunjukkan bahwa pembelajaran berorientasi pendekatan inkuiri meningkatkan motivasi siswa mempelajari fisika.

\section{Hasil Belajar Siswa}

Peningkatan juga ditunjukkan hasil belajar siswa. Peningkatan ini terlihat dari kenaikan persentase ketuntasan klasikal siswa. Rangkuman peningkatan tersebut dapat dilihat pada Tabel 8. Tabel 8 memperlihatkan terjadi peningkatan signifikan ketuntasan belajar siswa. Ini berarti, dengan melaksanakan pembelajaran fisika menggunakan pendekatan inkuiri di kelas hasil belajar siswa telah berhasil diningkatkan secara signifikan.

\section{H. Pembahasan}

\section{a. Motivasi Belajar Siswa}

Tindakan pada siklus I masih belum berdampak signifikan dalam pembelajaran. Ini terlihat dari jumlah siswa yang kurang termotivasi. Angket respon belajar siswa menunjukkan $32 \%$ siswa kurang termotivasi belajar fisika. Ragu bertanya atau menjawab pertanyaan adalah salah satu indikator yang menjadi catatan peneliti. Mereka ragu akan pertanyaan atau jawaban yang diberikannya Keraguan ini muncul karena siswa khawatir keliru atau salah. Sebagian lainnya menganggap apabila argumennya tidak sesuai atau jawabannya salah akan ditertawakan oleh teman lainnya.
Catatan lapangan selama siklus I menunjukkan motivasi siswa dalam mencari sumber-sumber yang relevan dengan konsep sangat rendah. Siswa hanya terfokus pada satu sumber buku yang dirujuk guru atau buku yang terdapat di perpustakaaan sekolah. Akhirnya referensi siswa menjadi minim Dampaknya terlihat dari tugas sekolah, atau pun tugas rumah (PR) menjadi sulit dikerjakan siswa apabila tugas tersebutu tidak terdapat dalam buku teks.

Motivasi belajar siswa mengikuti pembelajaran fisika berorientasi pendekatan inkuiri meningkat pada siklus II. Pendekatan dan motivasi yang diberikan guru menumbuhkan kepercayaan diri siswa dalam bertanya dan menjawab. Siswa tidak ragu menjawab dan memberikan argumen pada setiap pertanyaan yang diberikan guru. Lebih lanjut dalam mencari sumber pembelajaran, siswa mulai membiasakan diri untuk memanfaatkan perpustakaan dan mencari sumber-sumber melalui internet. Motivasi siswa dalam mempresentasikan hasil dari kegiatan berupa produk, kesimpulan maupun grafik meningkat dengan signifikan.

(Dimiyati \& Mujiono, 1994) menyatakan "motivasi merupakan kekuatan mental dalam diri siswa yang menjadi penggerak belajar." Ini berarti bahwa keinginan siswa belajar haruslah mendapat dorongan dari dalam diri siswa. Dorongan ini muncul karena pembelajaran yang dilakukan guru bersesuain dengan tujuan tepat sasaran dan dibutuhkan siswa dalam kehidupan sehari-hari. Motivasi siswa belajar haruslah mengandung dan memunculkan harapan siswa bagi masa depan yang lebih baik.

Tabel 7. Peningkatan Motivasi Belajar Siswa Setiap Siklus

\begin{tabular}{cccc}
\hline \multirow{2}{*}{ Siklus } & \multicolumn{3}{c}{ Persentase Rata-Rata Motivasi } \\
\cline { 2 - 4 } & Kurang Termotivasi & Termotivasi & Sangat Termotivasi \\
\hline I & 32 & 54 & 14 \\
II & - & 28 & 72 \\
\hline
\end{tabular}

Tabel 8. Peningkatan Ketuntasan Klasikal pada Tiap Siklus

\begin{tabular}{ccc}
\hline \multirow{2}{*}{ siklus } & \multicolumn{2}{c}{ persentase jumlah siswa } \\
\cline { 2 - 3 } & Tidak tuntas & tuntas \\
\hline I & 50 & 50 \\
II & 7 & 93 \\
\hline
\end{tabular}


Perilaku belajar siswa akan terbentuk melalui keadaan kejiwaan dan kekuatan mental di atas. Selama pembelajaran fisika berorientasi pendekatan inkuiri siswa dilibatkan dalam mencari dan merumuskan konsep-konsep fisika melalui percobaan-percobaan sederhana. Akibatnya siswa memiliki motivasi yang kuat mencapai tujuan pembelajaran. Jadi selama pembelajaran fisika berorientasi pendekatan inkuiri siswa didorong untuk aktif selama pembelajaran.

\section{b. Hasil Belajar Siswa}

Setelah tindakan tiap siklus memperlihatkan peningkatan hasil belajar siswa. Ini ditunjukkan melalui hasil analisis ketuntasan belajar individual siswa. Analisis hasil belajar menggambarkan peningkatan ketuntasan klasikal dari 50\% menjadi 93\%. Peningkatan ini terjadi setelah perbaikan tindakan pada siklus II. Selama pembelajaran siswa menjadi lebih antusias. Siswa tidak ragu atau cemas menghadapi ulangan harian.

Penggunaan pendekatan inkuiri pada pembelajaran merubah proses kegiatan pembelajaran di kelas. Guru tidak lagi menjadi pusat pembelajaran. Pembelajaran berorientasi pada aktivitas siswa. Paradigma pembelajaran pun berubah, guru adalah motivator dan fasilitator bukan pemberi informasi. Guru memotivasi dan memfasilitasi siswa untuk mencari informasi dan konsep-konsep fisika yang baru. Jadi siswa sendirilah yang aktif mencari dan mengolah sendiri informasi, data, dan fakta untuk merumuskan konsep-konsep fisika.

Pembelajaran fisika berorientasi pendekatan inkuiri memudahkan siswa memahami konsep-konsep dasar fisika. Siswa juga terbantu dalam menggunakan ingatan dalam jangka panjang karena mengalami dan merumuskan sendiri konsep-konsep fisika tersebut. Keterlibatan secara langsung dalam menemukan konsep fisika membuat siswa didorong untuk berfikir dan bekerja atas inisiatifnya sendiri. Hal ini membantu siswa mempelajari konsep-konsep fisika pada situasisituasi yang baru.

Pembelajaran fisika berorientasi pendekatan inkuiri juga mengharuskan siswa belajar menggunakan berbagai jenis sumber belajar. Melalui percobaan-percobaan sederhana siswa dapat menjadikan alat dan bahan dapat ditemukan di lingkungan siswa sebagai sumber belajar baru. Jadi pembelajaran fisika berorientasi pendekatan inkuiri memperkaya siswa akan konsep fisika. Pemahaman siswa terhadap materi yang dipelajari menjadi lebih baik. Hal ini berdampak pengetahuan yang diperoleh bertahan lama dalam ingatan siswa.

Penerapan pembelajaran fisika berorientasi pendekatan inkuiri meningkatkan keinginan siswa untuk menguasai materi pelajaran. Siswa memiliki keinginan kuat untuk mempersiapkan diri secara maksimal. Keinginan inilah yang menyebabkan kegiatan pembelajaran yang awalnya membosankan diikuti oleh siswa dengan antusias. Siswa menjadi aktif dan kreatif selama kegiatan belajar berlangsung.

Peningkatan kemampuan siswa mempelajari materi ajar menandakan bahwa siswa telah memiliki kemampuan setelah mendapatkan pengalaman belajar. Peningkatan ini berdampak pada peningkatan hasil belajarnya. Menurut (Sudjana, 2010) "hasil belajar adalah kemampuan yang dimiliki siswa setelah ia menerima pengalaman belajarnya." Artinya, melalui pembelajaran fisika berorientasi pendekatan inkuiri hasil belajar siswa dapat ditingkatkan.

Penelitian Mahesty sebelumnya juga menyatakan bahwa model pembelajaran inkuiri berbantuan laboratorium virtual dapat meningkatkan penguasaan konsep fisika siswa. Hal sama juga ditunjukkan oleh hasil penelitian (Saptaputra, 2018) terhadap siswa SMKN 7 Bandung juga menunjukkan penerapan metode inkuiri terbimbing dapat meningkatkan hasil belajar dan kemampuan metal siswa beraktivitas. Selain itu hasil bersesuaian ditunjukkan oleh penelitian (Umami \& Jatmiko, 2013). Penerapan model pembelajaran inkuiri dengan pendekatan SETS dapat meningkatkan keterampilan berpikir kritis siswa.

\section{KESIMPULAN DAN SARAN}

Hasil tindakan, pengamatan dan hasil refleksi selama penelitian disimpulkan sebagai berikut ini.

1. Pembelajaran fisika berorientasi pendekatan inkuri dapat meningkatkan dapat meningkatkan motivasi belajar siswa kelas XI IPA-1 SMAN 1 Batang Gasan TP. 2018/2019. 
2. Pembelajaran fisika berorientasi pendekatan inkuri dapat meningkatkan dapat meningkatkan hasil belajar siswa kelas XI IPA-1 SMAN 1 Batang Gasan TP. 2018/2019.

\section{DAFTAR KEPUSTAKAAN}

Dahar, R. W. (2012). Teori-teori belajar dan pembelajaran. Jakarta: Erlangga.

Dimiyati, \& Mujiono. (1994). Belajar dan Pembelajaran. Jakarta: Rineka Cipta.

Kusdiastuti, M., Harjono, A., Sahidu, H., \& Gunawan. (2016). Pengaruh Model Pembelajaran Inkuiri Berbantuan Laboratorium Virtual Terhadap Penguasaan Konsep Fisika Peserta Didik. Jurnal Pendidikan Fisika Dan Teknologi, II(3), 116-122.

Riduan. (2009). Belajar Mudah Penelitian untuk Guru, Karyawan dan Peneliti Pemula. Bandung: Alfabeta.

Sanjaya, W. (2008). Strategi Pembelajaran
Berorientasi Standar Proses Pendidikan. Jakarta: Kencana.

Saptaputra, B. W. (2018). Penerapan Metode Inkuiri Terbimbing untuk Meningkatkan Hasil Belajar Fisika Siswa. Jurnal Pelitian Pendidikan, 18(2), 124-134.

Silberman, M. L. (2006). Active Learning: 101 Cara Belajar Siswa Aktif. Bandung: Nusamedia.

Sudjana, N. (2010). Penelitian hasil proses belajar mengajar. Bandung: Remaja Rosdakarya.

Umami, R., \& Jatmiko, B. (2013). Penerapan Model Pembelajaran Inkuiri dengan Pendekatan SETS (Science, Environment, Technology and Society) pada Pokok Bahasan Fluida Statis untuk Meningkatkan Keterampilan Berpikir Skritis Siswa Kelas XI SMA Negeri 1 Gedangan. Jurnal Inovasi Pendidikan Fisika, 02(03), 61-69. 